\title{
Los Girasoles
}

Emilia Yang

(C) UNAN-Managua

Recibido: abril 2018

Aprobado: junio 2018

DOI: https://doi.org/10.5377/rll.v5i1.8976

(c) (i) (9)

La tarde de Managua se deshacía y los árboles de la vida iluminaban el camino amarillo detrás de la rotonda. Mari caminaba rápido entre la gente por el bulevar para encontrarse con sus compañeras frente a Plaza Inter. Las tres han trabajado juntas en el mismo punto desde que cerraron el Elite.

¿Todo eso es tuyo amor?! preguntó Luz mientras la revisaba de arriba a abajo. Su cuerpo voluptuoso le da juventud, sus ojos dureza.

Sí, tierna, ahí donde me ves yo sí gasto para andar bella. No voy a andar toda haraposa como vos. Mari subía el mentón y sacaba su polvera para repintarse los labios en rojo.

Ay mírala, anda toda cubierta, hasta parece seria. Sandy le señalaba el pecho.

Es que vengo de capacitación con el Consejo, entre susurros Mari les confiaba apenada.

¡Sólo verga sos! Le reclamó Sandy, la más pequeña de las tres, quien se acomodaba sus sandalias y el busto para alcanzar en su vestido celeste.

Ay déjame ser, así soy feliz.

Oí, jajaja, que la puta ahora quiere ser leguleya.

Piensen lo que quieran, ahora así nos vamos a defender y nadie nos va a hacer mates, ni la pesca. Ya denunciamos al hombre que le rayó la cara la Rosita, está preso y le vamos a dar seguimiento. Con eso yo me conformo.

No jodás, sonás a anuncio de radio vos. Sólo te falta que me mandés al culto. Se rió Sandy para sí misma pensando; ésta jodida sólo quiere andar de vaga con los policías del barrio.

Mari continuó su discurso; Ustedes no me creen. La Juana ahora es promotora de salud, yo voy a trabajar en las elecciones. El gobierno nos apoya. Hasta vamos a cambiar las leyes. Mi comandante tiene mi voto.

A pesar que Sandy no sabía leer, estaba segura que no quería tener nada que ver con un sistema que siempre se había olvidado de ellas.

Yo no sé, algo se anda la Chayo entre manos. A mí no me van a comprar. Por eso soy puta. Además, ya pronto me voy a la verga de aquí.

Oscurecía y Sandy recibió una llamada. Mari cambió de tema porque estaba aburrida y sabía que a quién debía convencer de organizarse era a Sandy. 


\section{Revista de Lengua y Literatura. Vol.5, núm. 1, enero-junio 2019}

Oíme, ahí cerca andaba tu cliente, el de las siete.

Sí, ya me chatió. Ese hombre es bien bueno, vieras vos, paga bien y hasta sabe riquísima su turca, le dijo Luz sobándose los brazos.

Yo sueño con cogerme a ese comisionado guapo. El que me toca a las diez no me gusta, porque sólo por el culo le gusta, dice que su mujer no se lo presta.

Sandy regresó al círculo sonriente y Mari inmediatamente leyó su sonrisa:

Ese taxero desgraciado te va a arruinar, hijueputa.

Nombre, ya quedé vacunada con el hombre mierda ese.

No me vuelvo a enamorar...

Pero es que a veces, sólo con pensar en él, ya siento que me vengo. No sé si estoy enamorada, pero a veces sólo con verlo, me siento bien cosquilluda.

Luz tampoco confiaba en el taxista

Ese hombre no te quiere, tiene otras seis mujeres. Dale su taconazo en el culo ya.

Me quiere, hasta metió preso al piedrero de mi hermano por robarme el celular y me dio uno nuevo, les aseguró Sandy.

La noche siguió en su ritmo de idas y venidas de las tres. Dueñas de un lugar sin dueño. Un ajetreo imperceptible para los que no las conocieran o no las estuvieran buscando. Las luces cambiaban, pero siempre una de ellas estaba en su esquina, acercándose a los carros desconocidos que pasaban lentamente en búsqueda de sexo y afecto.

El taxista llegó puntual a las 3. Pitó varias veces. Luz no estaba y Mari le dijo a Sandy como si fuera su hermana mayor,

Cuídate amor, que no ande bolo o drogado, ahí nos vemos mañana.

Sandy se sentó en el taxi que olía a aceite de pino fresco. El taxista estaba revisando su celular. Sandy le dio un beso tibio y largo, y le compartió sus sueños con inocencia.

Fijate, que me quiero ir a Corinto, dicen que ahí están mejor las cosas y te pagan en dólares.

Sandy vio cómo al taxista le cambió el semblante ante sus planes.

¿Desde cuándo andás con esa idea? ¿Cuándo me lo pensabas decir?

El taxi circulaba la rotonda vacía en camino al Gallo Pinto.

Pues, no sé, desde hace poco...Peeero yo no sé cuál es tu problema, aquí nadie es de nadie y vos lo sabés, Sandy encendió un cigarro enojada. 
No, no lo sé, le dijo él.

Siguieron el camino en silencio mientras él manejaba y tocía y Sandy fumaba. Cuando llegaron al motel él le abrió la puerta, la hizo entrar y en un segundo la tenía acostada en la cama con las piernas arriba. Ella no tenía ganas en ese momento. A pesar que lo sentía duro moviéndose en las paredes dentro de su vientre. Estaba amargada con su respuesta. Abajo de él veía su reflejo en el espejo manchado que guindaba del techo del motel sin reconocerse. Vio sus lunares y su pelo negro sobre la cama. Contemplaba sus nalgas, apretándose encima de ella, restregando todo su cuerpo pesado sobre ella. Sandy se tele transportó a Corinto, fingiendo placer, gimiendo fingidamente. Se sintió flotando en el mar, la brisa en su cara, el olor a pescado frito cercano. Entretuvo las posibilidades de irse en un crucero de esos que llegan al puerto e irse aún más lejos donde nadie la conociese, ni la buscase. Reinventarse. Sentirse libre, soberana y serena.

Él terminó con un ruido ronco y profundo, como sacándose una ira contenida de tres días. Se sacudió hacia al baño para quitarse el condón. Enseguida la estampó contra la pared y le retorció el pelo largo entre sus manos. Sandy no sabía que pasaba. Cayó en cuatro y sintió como él le metió una patada en la nariz y otro mucho más fuerte en el estómago. Sólo vio cómo su vestido se marcaba con rayas rojas.

¿Que sos mía y si vos me dejás, te mato y me mato yo!

No lo hagás. No me voy a ir. Por favor no.

Afuera estaba Luz que acababa de terminar con un cliente, oyó los gritos de súplica de Sandy y se regresó. Le dijo al dueño del Gallo Pinto que le abriera que su amiga estaba adentro. ¡Moveme, me duele! gritó Sandy. Luz logró moverla afuera en medio del pánico, pero se le vino una bocanada llena de sangre y expiró.

Al día siguiente Mari estaba en la estación hablando con su comisionado. Le confirmó que están investigando el caso y que el taxista se dio a la fuga.

A veces Mari y Luz se encuentran. Ya no lloran ni hablan de política. 